\title{
A Critical Analysis of the Diaoyu Islands Dispute in American News Media
}

\author{
Xin $\operatorname{Jin}^{1} \&$ Yan Shang ${ }^{1}$ \\ ${ }^{1}$ School of Foreign Languages, Jiangsu University, Zhenjiang, China \\ Correspondence: Xin Jin, School of Foreign Languages, Jiangsu University, Zhenjiang, 301 Xuefu Road, \\ Jingkou District, Jiangsu, China. E-mail: 1004565860@qq.com
}

$\begin{array}{lll}\text { Received: December 22, } 2014 & \text { Accepted: January 5, } 2015 \text { Online Published: March 29, } 2015 \\ \text { doi:10.5539/ijel.v5n2p55 } & \text { URL: http//dx doi.org/10.5539/ijel.v5n2p55 }\end{array}$

doi:10.5539/ijel.v5n2p55 URL: http://dx.doi.org/10.5539/ijel.v5n2p55

\begin{abstract}
Critical linguistics, also called critical discourse analysis (CDA), is a new subject which is based on linguistics as well as the achievements of scientific researches in the field of sociology, psychology, and mass media etc. It aims to penetrate the linguistic forms of discourse and then disclose how ideology influences discourse as well as how discourse affects ideology from various angles. The paper applies Halliday's (2000) functional model and Fairclough's (1989) model of CDA to make a quantitative and qualitative analysis on the eight news reports about Diaoyu Islands in the TIME magazine in 2012. The author takes Transitivity, Transformation and Modality as analytical tools to analyze the news report discourse. Through the analysis, the author finds that the seemingly objective news reports of American media are not merely the reflections of the reality, and the author tries to reveal the different ideologies hidden in them so that readers may have a better understanding of news discourse and news criticism as well.
\end{abstract}

Keywords: critical discourse analysis, news reports, Diaoyu Islands, analytical tools, ideology

\section{Introduction}

In modern times, the mass media, such as newspapers, magazines, broadcasts etc. are playing an increasingly important role in people's everyday life. Media discourse, news discourse in particular, which has become a primary source of information, may standardize and control social life and personal values.

News is generally believed to be objective, impartial and unambiguous. In recent years, however, this viewpoint has been challenged by scholars in the field of mass communication, sociology and linguistics as well. Basing on the theory of critical discourse analysis (CDA), which is a branch of instrumental linguistics initiated by Fowler in the late 1970s, researchers intend to testify that although language in news reports is always claimed to be neutral, credible and undistorting, it is often laden with values and ideologies. They employ CDA to investigate how news discourse constructs representations of the world, social relationships and hidden ideologies. According to Van Dijk (1998), CDA attempts to uncover the discursive sources of inequality and power relations and further to reveal the sociocultural contexts in which these discursive sources originate.

The present study of news reports on the Diaoyu Islands is done as a response to the current social background. In this event, as a third party, Americans' ideas could easily show its political tendency. The author will select eight news reports of the TIME magazine in 2012 and analyze the hidden meaning which may stand for Americans' attitudes.

\section{Literature Review}

\subsection{Previous Studies of CDA}

Critical discourse analysis (CDA) emerged in the late 1980s as programmatic development in European discourse studies spearheaded by Norman Fairclough (1989), Ruth Wodak (1989) and Van Dijk (1998). Since then, it has become one of the most influential and visible branches of discourse analysis, as can be seen in the anthology by Jaworski \& Coupland (1999). It mainly adopts Halliday's systematic functional grammar as theoretical basis to analyze political discourse. In this way, the ideology and power hidden in the over representations can be explored. Ruth Wodak's (1989) definition about CDA is that it is "an interdisciplinary approach to the language study with a critical point of view" (Xiong, 2009, p. 28). Its purpose is to study "language behavior in natural speech situation of social relevance" (ibid.). On the basis of summarizing the work 
in CDA, Kress's explanation of CDA is that it has "the larger political aim of putting the forms of texts, the processes of production of texts, and the process of reading, together with the structure of power that have given rise to them. into crisis" (ibid.).

In general, CDA's main purpose is to uncover the dialectical connections between discourse practice, social practice, and social structures, connections that might be hard to understand for person who are not familiar with this theory.

\subsection{Previous Studies of Critical Analysis of News Report}

Norman Fairclough (1989) proposes the theories underpinning CDA and analyzes a variety of textual Examples to illustrate his theories. His three dimensional model is adopted as the theoretical framework in many studies and in the present study as well. He analyzes a news report from the British newspaper Sun which mixes its own populist, conversation-like style with the bureaucratic language of the document on which it is reporting. Fairclough (1989) also applies his three dimensional framework to a case study on the political discourse of Thatcherism, in which he investigates the institutional and social contexts rather than the linguistic features themselves.

Van Dijk (1998) analyses news reports in many languages. His comprehensive studies and Published works facilitate the development of critical news analysis. His earlier works focus on literary studies and text grammar. Since the late 1980s, he turns to media discourse. His interest is in "developing a theoretical model that will explain cognitive discourse processing mechanisms" (Xiong, 2009, p. 30). He develops a cognitive model for CDA and concentrates on the interpretation of the text by the subjects in a psychological perspective. His main contribution is a framework for analyzing the discourse structure of news reports. Recently, he turns attention to the relations of power, language and ideology in news discourse and the study of political discourse and racism.

From 1990s, Chinese scholars have discussed the news discourse from the perspective of CDA. They argued that the choices of the news discourse reflect the newspaper's position and viewpoints, and the objectivity of the news press is relative. Chen Zhongzhu (1995) is one of the pioneers of the critical linguistics and the CDA study in China. Chen introduced the general concepts of CDA, including its development, the philosophical foundation and the methodology. He discussed the transitivity system and interpersonal system in some news cases and predicted that the CDA study would be a tendency of linguistic studies in China.

Xin Bin (2005) is a prominent figure in critical news analysis at home. He has continually worked on critical linguistics and CDA since 1996, and has contributed to the development of CDA in China. He proposes that comparative study on news discourse is very useful. In his work, he makes comparative studies on news reports from different newspapers reporting the same event. He mainly concentrates on the factors such as classification, nominalization, passivization, tense and voice, modality and intertextuality.

The above review shows that many achievements have been made due to the continuous efforts of the analysts at home and abroad. However, there has been a lot to be done. We find the traditional structural and stylistic studies focuses on the language features of the news and relations of internal elements of the language system, while the critical analysis deals with the ideological, social and historical assumptions embedded in news contexts, or relations between internal and external factors of the discourse. All the scholars' theoretical and practical contributions to news discourse have given the author an inspiration of this study.

\section{Theoretical Framework}

\subsection{Fairclough's Three Dimensional Framework}

In Fairclough's model (1989), the discourse to be analyzed should be divided into three dimensions. They are texts, interactions and contexts. Text refers to transcripts of political discourse addressed by some politicians. Interactions concerns that the process of production and consumption of political speech. Context refers to cultural and social structures which give rise to the communicative event. What need to be mentioned here is that the meaning of the three dimensions varied slightly from different works and the framework is still under improvement. For example, in another works by Fairclough_Media Discourse, the second and third dimension are termed "discourse practice" and "sociocultural practice". However, the central meaning of the three concepts is basically unshakable.

Basing on the three dimensional relationship of discourse, Fairclough puts forwards relative theories to conduct the analysis, that is, the three-dimensional framework.

To handle the relationship of the three dimensions requires three types of analyses, which are text analysis, processing analysis and social analysis. In the first dimension, analysis should include choices and patterns in 
vocabulary (e.g., wording, metaphor), grammar (e.g., transitivity, modality), cohesion (e.g., conjunction, schemata), and text structure (e.g., episoding, turn-taking system). In the second dimension, it involves the production and consumption of texts. Analysis of vocabulary, grammar, cohesion and attention should focus on how a discourse is linked within a context. The third dimension means that CDA should also commit to analyze the relationship between text, process and social conditions, both immediate conditions of social context and more remote conditions of institutional and social structure.

\subsection{Halliday's Systemic-functional Grammar}

Systemic-functional linguistics approaches language with the help of social context, which functions as a tool of social interaction, instead of formal, cognitive system without taking social context into consideration. According to Systemic-functional linguistics, there are three metafunctions - the ideational metafunction of representing the world, the interpersonal metafunction of interaction in the clause and textual metafunction of organizing the massage (Halliday, 2000, p. 54).

The ideational metafunction uses language to represent experience of the world, including experiential meanings and logical meanings. Thus, Halliday (2000) further categorizes ideational metafunction into experiential metafunction and logical metafunction. The ideational metafunction serves to express both people's experience of the outside world and their inner world of consciousness. The ideational function is mainly realized by vocabulary or lexis and transitivity system, which "construe the world of experience into a manageable set of process types" (Wu, 2008, p. 54).

The interpersonal metafunction means that speakers can use language expressions to convey their comments, attitudes, evaluations and also to set up and maintain social relationship between themselves and their listeners, and possibly further to influence others' attitudes or behaviors. To put it simply, the interpersonal metafunction refers to the relationship between the speaker and the hearer. It is realized mainly through mood and modality. The current study probes the most important element of the interpersonal function-modality (Halliday, 2000, p. 58).

The textual metafunction is concerned with the creation of a text. It is through this function that language makes link with itself and with the situation; and discourse becomes possible, because the speaker or the writer can produce a text and the listener or reader can recognize one (Tang, 2008, p. 89). The textual metafunction fulfills the requirement that language should be operationally relevant, having texture in a real context of situation that distinguishes a living passage from a mere entry in grammar or a dictionary (ibid.). When people are talking about their experience of the world or interacting with other people, they should make the conveyed massage into a coherent whole.

\subsection{Analytical Tools}

Any method that is helpful to critical linguistics should be advocated and developed. However, not all of them have to be helpful in the same discourse and it is not necessary to use all the devices or to use them in exactly the same way in specific research projects. The selection and application of the tools mainly depend on the research questions and the data characteristics.

Therefore, the author will apply these analytic tools to a specific contrastive analysis on the basis of the theories that we have laid out in the previous parts.

\subsubsection{Transitivity}

Transitivity is a key analytical component of the ideational metafunction. It shows how language users encode in language their mental pictures of reality and how they account for their experience of the world around them. Thus it can be seen that transitivity can disclose the speaker's intention and motivation. The way in which transitivity carries out this ideational function is expressed by processes, such as material processes, mental processes, relational processes and so on. The material process is identified with verbs like 'doing', 'happing', 'being', 'exiting', etc. that is to inform people what is happening. This feature conforms to the basic task of news reporting - to report stories objectively, so it seems not so subjective as other processes. Verbal processes are mainly realized by words like 'say', 'report' etc. which are followed by either a direct or indirect speech. They are the most reliable sources of the reported stories. Relational process is a process of 'being', a representation of the relations among things. By relational process, an occasional action can be transferred into a stable or even permanent state. This process usually provides readers with some necessary background information and relevant explanations to clarify the subtle relationships and the ideology involved in. 


\subsubsection{Transformation}

Transitivity analysis is a semantic perspective on the ideas expressed by a clause. It is a proposition about the world, in which an event, situation, relation or attribute is predicted of some participants. But a clause, basically, is a syntactic unit, a pattern of ordering of words and phrases. Here transformation refers to the syntactic variation, or we may say, alternative phrasing. Just as there are various processes to be employed, the ordering of words and phrases is also optional, such as passivization, making the affected participant in the focal subject position and classification, revealing the reporter's stand point and his hidden ideology.

\subsubsection{Modality}

Modality refers broadly to a speaker's attitude towards, or opinion about, the truth of a proposition expressed by a sentence. It also extends to their attitude towards the situation or event described by a sentence. In any prepositional utterance, the producer must indicate what Hodge Kress (1988) (Xiong, 2009, p. 63) call a degree of 'affinity' with the proposition, so any utterance has the property of modality. To quote from Fowler, 'modality' is a device to indicate speakers' attitudes, and these attitudes fall into the areas of validity, predictability, desirability, obligation, and permission. In the addresser-addressee relation, the American reporters put themselves a 'superior' position and the addressee the 'inferior'.

\section{A Critical Analysis of American News Reports on Diaoyu Islands}

This part will be devoted to a critical analysis of American news reports on Diaoyu Islands. Halliday and Hasan (1985) point out that the ultimate purpose of discourse analysis is not "interpretation" but "explanation", that is, an explanation how a message is conveyed. Therefore, in the critical study of this thesis, the language Example discourse at different levels of textual structures will be analyzed and compared, and then the author will venture to explain the reasons for these features.

\subsection{Sample Discourse}

\subsubsection{Data Collection}

This paper is a critical study of American's news reports on the Diaoyu Islands with the aim to reveal the deep relationship between language, power and ideology. In particular, the present study tends to cultivate readers' critical awareness so that they may become more active receivers when reading news reports. These readers may understand news reports about the Diaoyu Islands much better than before. The writer tends to prove her viewpoints with typical examples in the following analysis.

This paper takes eight authentic news report discourses (2012) on the Diaoyu Islands. All of the Example discourses are from the website of the TIME, which started publication in 1923 and is one of the most important magazines published in the world. Even some linguists said that reading the TIME is a convenient way to study American English.

\subsubsection{The Background Story of the Examples}

On September 7th, 2012, a Chinese fishing boat hit two Japanese ships near China's Diaoyu Islands. Japanese police kept the Chinese boat for days. They say the Chinese boat broke Japanese fishing law. However, Diaoyu Islands are part of China. Japan has no right to use their law there. China protested Japan many times since this happened. A few days later, Japan let the fishing boat and 14 Chinese fishermen go free. But they still kept the Chinese captain, until September 25.

China's claim over the Diaoyu Islands dates back to the early $15^{\text {th }}$ century. The Imperial Map of Ming Dynasty included them as part of Ming Empire's territory. After the Ming Dynasty, documents show the islands remained as part of China. That was until 1895, when Japan forced China to give up Taiwan and some islands to Japan, the Diaoyu Islands included. After World War II, international documents recognized Taiwan and the islands around it as falling under Chinese territory. But the administration of the islands fell into Japanese hands in 1972. In September 2012, the Japanese government purchased the remaining three of the disputed islands that it did not already own from their "private owner", so this event prompting a large-scale protests in China.

\subsection{The Critical Discourse Analysis with Analytical Tools}

\subsubsection{Transitivity}

The following table illustrates a general feature - the distribution of process types in the eight articles: 
Table 1 . The distribution of transitivity types in news examples

\begin{tabular}{lllllll}
\hline Process Types & $\begin{array}{l}\text { Material } \\
\text { Process }\end{array}$ & Mental Process & $\begin{array}{l}\text { Relational } \\
\text { Process }\end{array}$ & Verbal Process & $\begin{array}{l}\text { Behavioral } \\
\text { Process }\end{array}$ & $\begin{array}{l}\text { Existential } \\
\text { Process }\end{array}$ \\
\hline Percentage & $39 \%$ & $16 \%$ & $23 \%$ & $13 \%$ & $4 \%$ & $5 \%$ \\
\hline
\end{tabular}

\subsubsection{Material Process}

From the above table, it is clear that material processes occupy $39 \%$ among all the processes. This predominant position conforms to the idea that these reports are quite objective to some extent.

\subsubsection{Verbal Processes}

The verbal process is a process of saying. It accounts for $13 \%$ in the samples. As aforementioned, it is realized through different word meaning 'say' and followed by either direct or indirect speech so to show the source of the story. Let us look at the following three examples:

(1) A day later Chinese Foreign Minister Yang Jiechi slammed Japan for "outright denial" of the outcomes of World War II.( As Islands Dispute Simmers, China's Hu Calls for Rise of a Maritime Power, TIME. Nov 25, 2012)

(2) Japan says the Diaoyu were no man's land before 1895 and should be considered part of Okinawa. (Anti-Japan Protests Hit China's Capital, TIME. Sep 27, 2012)

(3) While the U.S. says it doesn't take a position on the island's sovereignty, it says that as they are administered by Japan they fall under the U.S.-Japan Mutual Defense Treaty, meaning the U.S. could be obligated to aid Japan in the event of an attack on them. (Anti-Japan Protests Hit China's Capital, TIME. Sep 27, 2012)

Example (1) and (2) are both official reports in response to the Diaoyu Islands. The word "slam" in Example 1 means denounce and criticize. By citing this word, the reporter vividly expressed Chinese Foreign Minister's rage. The word "say" in Example (2) leads to the direct speech of the source, Japan, which insisted that Diaoyu Islands belong to them. By citing from the sources, reporters represent the sayers' opinions and attitudes and avoid being responsible for the subjectivity or bias in the news discourse.

In Example (3), the sayer becomes a third participant—-the US and it favors Japan conspicuously. This Example clearly exposes the U.S. media favor the Japanese.

\subsubsection{Relational Processes}

Now the analysis moves to relational processes. The distribution in Table 1 reflects the importance of political issues lying not only in the facts, but also in the consequences and influences they may have. The following examples well illustrate it.

(4) In reality, of course, there is zero chance that the U.S. will honor its treaty obligation over a few barren rocks. (China: Island Dispute Spurs Anti-Japan Protests. TIME. Sep 20, 2012)

This example gives background information and the reporter's comment on Diaoyu Islands. With the development of China's navy ability, the U.S. won't risk conflicting with China. A cohering phrase 'in reality' and the relational process next imply the reporter's standpoint of the attitude of the U.S. with which the audience could clearly judges the Diaoyu Islands Dispute.

\subsubsection{Transformation}

The term 'Transformation' initially derives from Noam Chomsky. Critic also analyzes the clause from a syntactic perspective, which concerns position and sequence of elements, rather than their propositional meanings and functions. Here the paper mainly discusses one form: passivization.

Passive sentences are significant representational variants. Motivations for choosing passive voice are various. Critical linguists uphold that the choice of passive voice may be deliberately made because of personal, political and ideological reasons: the affected participant is brought to the focal subject position on the sequence, and the semantic agent can optionally deleted; the link between link and process is weakened, the casual connection $\mathrm{s}$ looser, and it may be difficult and impossible for readers to recover casually. The following are some examples from the TIME magazine.

(5) China argues the islands have long been recognized as its territory. (Anti-Japan Protests Hit China's Capital, TIME. Sep 27, 2012)

(6) Two units that Zhou thinks could be involved in a Senkaku/Diaoyu conflict. (Chinese View Of Islands 
Conflict: "Make It Quick". TIME. Sep 18, 2012)

(7) Estimates of Chinese who were killed during the conflict range as high as 20 million. (China: Island Dispute Spurs Anti-Japan Protests. TIME. Sep 20, 2012)

(8) "We see ourselves as having been defeated by the United States, not by China. So we don't have to be aware of the defeat when it comes to the relationship between Japan and China," Kurosawa says. (China: Island Dispute Spurs Anti-Japan Protests. TIME. Sep 20, 2012)

In Example (5) and (6), such passivization of sentence is common in English language because under such situation it is unnecessary to mention the AGENT. These two examples are normal usage. In Example (7), we can clearly see the intention of American media----through foregrounding the affected participants by means of passivization it draws the audience's notice to the Chinese and at the same time it weakens Japanese's cruel crimes. While in Example (8), the author deliberately stress the agent in order to speak in defense of Japan that Japanese are beaten by the U.S., so they don't have to lower themselves when facing China.

\subsubsection{Modality}

Modality is to realize the interpersonal functions of language. It expresses personal wills, obligations and presumptions of the events (Fowler, 1991, p. 85). In news reporting, the modality can be realized by modal verbs, modal adverbs, and modal adjectives and so on. Let's have a look at the following examples:

(9) But concerns remain over the potential for a clash or even an accidental collision that could see risk of fighting between the two sides. (Anti-Japan Protests Hit China's Capital. TIME. Sep 27, 2012)

(10) Should the economic climate of the Asia-Pacific region concurrently show positive growth, many countries will also have increased means to respond to security concerns (As Islands Dispute Simmers, China's Hu Calls for Rise of a Maritime Power. TIME. Nov 25, 2012).

(11) Given Ishihara's nationalistic views, such a purchase would have certainly have further escalated the dispute. (As Islands Dispute Simmers, China's Hu Calls for Rise of a Maritime Power. TIME. Nov 25, 2012).

In Example (9), the word 'could' suggests the reporter's judgment of the consequence of Diaoyu Islands Dispute, i.e. the potential of a clash between China and Japan still remains. The word 'should' in Example (10) is placed at first and this clause is in subjective mood, which implies that the author makes a hypothesis. With the word 'will', the author gives his opinion of the possibility of the Diaoyu Islands Dispute leading to another broad protest. 'would' in Example (11) refers to the possible result of the purchase. The highly use of modal words in the report implies the reporter's conjecture of the Diaoyu Islands Dispute, which makes its doom to offend the principle of news composing - being objective.

\subsubsection{Explanation of the Examples}

From above we can see that the U.S. media's news reports are somewhat biased against china. For this matter, there are a great number of explanations. Firstly, there exist ideological differences. Americans always have their own superiority and think they hold the truth, so they analyze and comment things from their perspective. Secondly, the government plays an important role in media field. American media often regard them as watchdog to supervise government to spread some special news. Thirdly, the journalists and reporters are lack of knowledge about Chinese and Chinese culture.

Ideologies are closely linked to language because language is the commonest form of social behavior. Since language is the kind of social behavior where we rely most on common-sense assumptions, ideology is embodied in language and beyond its user's awareness, and the same is true of discourses.

\subsection{Findings}

Through the thoroughly critical analysis on the news reports examples, the thesis finds out that the seemingly objective news reports of American media are not merely the reflections of the reality. They distort the facts subtlety through the choices of processes and words, the ordering of phrases, speech representation as well as the selection of auxiliary verbs. American media's news discourses leave the readers a illusion that the Japanese's acts are legal. Taking China's rapid development into consideration, the American media seize this opportunity to disgrace China's image so as to impose pressure on its government.

\section{Conclusion}

Adopting the CDA approach to media discourse, the present study has analyzed and discussed the news reports related to the issue of Diaoyu Islands Dispute from the TIME magazine based on Fairclough's TDM and Halliday's SFL. In the previous chapter, a detailed analysis is conducted following the procedures of description, 
interpretation and explanation. The first stage of description is conducted on the three metafunctions focusing on lexical choices, transitivity system and modality. The second stage of interpretation focuses on the analysis of news sources. As to the last stage of explanation, institutional context, situational context, and sociocultural context in which the news reports are produced and interpreted are analyzed. The major findings and implications as well as limitations and suggestions are presented below. There are definitely some limitations in this study.

First, the data undergoing the analysis is not plenty. Due to the limitation of time and energy, only a few pieces of news reports are collected from the TIME magazine.

Secondly, the analysis may be subjective to some extent in that every stage of the analysis involves the author's own interpretation.

Thirdly, the present qualitative and quantitative study both needs improvement.

Given the limitation of the present study, it is hoped that future analysts can consciously learn more knowledge about the social and cultural structures in the west and conduct analysis based on a more comprehensive source of news Example on the event by keeping up with the whole process of the development of the event.

Besides, because of contemporary changes affecting the role of language in social life, critical language awareness becomes a prerequisite for effective democratic citizenship, and should therefore be seen as an entitlement of citizens, especially children developing towards citizenship in the education system. CDA provides theoretical basis for the promotion of pedagogical practice to guide students in discovering the unspoken and unwritten words instead of solely paying attention to grammar, vocabulary and sentence structure. And the critical approach toward discourse might be applied to develop Chinese students' ability to critical reading and thinking, and provide some enlightenment for the teaching of reading in foreign language teaching.

\section{References}

Chen, Z. Z. (1995). 批评语言学评述. Beijing: Foreign Language Teaching and Research Press.

Fairclough, N. (1989). Language Power. Harlow: Longman Group UK Limited.

Fairclough, N. (1995). Media Discourse Analysis: the Critical Study of Language. London: Edward Arnold.

Fowler, R. (1991). Language in the News: Discourse and Ideology in the News. London Routledge.

Halliday, M. A. K. (2000). An Introduction to Functional Grammar. Beijing: Foreign Language Teaching and Research Press.

Halliday, M. A. K., \& Hasan, R. (1985). Language, Context and Text: Aspects of Language in a Socio-semiotic Perspective. Victoria: Deakin University Press.

Ji, W. N. (2008). 话语分析——批判学派的多维视角评析. Foreign Language Research, (6), 35.

Kress, G., \& Hodge, R. (1988). Social Semiotics. Cambridge: Polity Press.

Tang, L. (2008). 对美国新闻媒体中国报道的批判性话语分析. Unpublished Master's dissertation, Zhejiang University, Hangzhou.

Van Dijk, T. A. (1998). Critical discourse analysis. In Tannen (Ed.), Handbook of Discourse Analysis (p. 25). Oxford: Blackwell.

Wodak, R. (1989). Language Power and Ideology. Amsterdam Philadelphia: John Benjamins. http://dx.doi.org/10.1075/ct.7

Wu，L. (2008). 美国报刊对华新闻报道中评价语言的批评性话语分析. Unpublished Master's dissertation, North China Electric Power University, Baoding.

Xin, B. (2005). 批评语言学: 理论与应用. Shanghai: Shanghai Foreign Languages Education Press.

Xiong, S. (2009). 中西方关于奥运火炬传递受阻新闻报道的批评性对比分析. Unpublished Master's dissertation, Huazhong Normal University, Wuhan.

Spitzer, K. (May 14, 2012). Clock Ticks on China-Japan Islands Dispute. TIME. Retrieved from http://world.time.com /2012/05/27/clock-ticks-on-china-japan-islands-dispute-battleland/

Beech, H. (Sep. 12, 2012). Anti-Japan Protests Reach Fever Pitch as Panetta Visits Beijing. TIME. Retrieved from http://world.time.com/2012/09/18/anti-japan-protests-reach-fever-pitch-as-panetta-visits-beijing/

Ramzy, A. (Sep. 14, 2012). Tensions with Japan Increase as China Sends Patrol Boats to Disputed Islands. TIME. Retrieved from http//www.cbsnews.com/news/china-sends-patrol-boats-to-disputed-islands/ 
Spitzer, K. (Sep. 18, 2012). Chinese View of Islands Conflict: "Make It Quick". TIME. Retrieved from http://world.time.com/2012/09/18/chinese-view-of-islands-conflict-make-it -quick/

TIME Staff. (Sep. 20, 2012). China: Island Dispute Spurs Anti-Japan Protests. TIME. Retrieved from http://world.time.com

TIME Staff. (Sep. 27, 2012). Anti-Japan Protests Hit China's Capital. TIME. Retrieved from http://world.time.com

Spitzer, K. (Nov. 19, 2012). A Modest Proposal for Defending Japan's Remote Island. TIME. Retrieved from http://world.time.com

Ramzy, A. (Nov. 25, 2012). As Islands Dispute Simmers, China's Hu Calls for Rise of a Maritime Power. TIME. Retrieved from $\mathrm{http}: / /$ world.time.com/2012/11/08/as-islands-dispute-lingers-chinas-hu-calls-for-building-of-a-maritime-po wer/

\section{Copyrights}

Copyright for this article is retained by the author(s), with first publication rights granted to the journal.

This is an open-access article distributed under the terms and conditions of the Creative Commons Attribution license (http://creativecommons.org/licenses/by/3.0/). 